\title{
A culpabilidade e a relevância da política criminal
}

\section{The CULPABILITY AND THE RELEVANCE OF CRIMINAL POLICY}

\author{
Gabriel Bertin de Almeida * \\ Allan Vieira Lino **
}

Resumo: Esta pesquisa investiga o elemento culpabilidade dentro da estrutura do delito, estudando sua amplitude, sentido, relevância, assim como, dedutivamente aponta-se possíveis falhas e/ou inconsistências se estudado tão somente sob um aspecto isolado. Neste debate observa-se que a culpabilidade constitui verdadeiro elemento integrador a estrutura do delito, de modo que negá-lo como elemento do injusto culpável compreende notório retrocesso jurídico-penal. Outro ponto a ser abordado é no que tange ao fato da culpabilidade, antes de ser um fator puramente individual, ser entendida indubitavelmente como um fenômeno social, onde esta reprovabilidade não deve ser avaliada tão somente sob um prisma isolado e individualista do agente caracterizador da infração, mas sob o aspecto do seu meio social, produto de sua conduta. O presente trabalho tem como objetivo o estudo da culpabilidade, assim como a relevância que a Política Criminal desempenha diante da avaliação concreta da conduta do indivíduo.

Palavras-chave: Culpabilidade. Políticas criminais. Juízo social.

Abstract: This research investigates the culpability element within the structure of the offense, studying its magnitude , direction, relevance as well as deductively points are possible gaps and / or inconsistencies are studied so only under a single aspect. In this debate it is observed that culpability is true integrator structure of the offense so that deny it as an element of culpable unfair comprises notorious criminal legal setback. Another point to be made is in regard to the fact of guilt, rather than being a purely individual factor undoubtedly be understood as a social phenomenon, where this disapproval should not be evaluated solely on an isolated and individualistic prism of characterizing agent of offense but under the aspect of their social environment, the product of his conduct. The present work aims to study the guilt as well as the importance that plays on Criminal Policy of concrete assessment of the individual's conduct.

Keywords: Culpability. Criminal Policy. Social Judgment. 


\section{INTRODUÇÃO}

O presente artigo tem como objetivo o estudo da culpabilidade penal enquanto elemento limitador e fundamentador da pena, assim como as relevâncias que as 'políticas criminais' desempenham diante da avaliação concreta da conduta do indivíduo.

É notório compreender que a doutrina da teoria do delito muito avançou com o passar do tempo (assim como teve, também, alguns retrocessos), mas que, ainda continua sendo objeto de profundos estudos por nossos mais renomados doutrinadores e estudiosos das Ciências Criminais.

A culpabilidade penal, enquanto elemento nitidamente integrador da estrutura do delito, tem sido, sem dúvida alguma, o elemento que mais desperta interesse de estudo pelos operadores do direito, pois tal elemento representa um juízo de valor destinado à conduta do agente infrator da norma, na qual, o sujeito, diante de diversas situações, pode ser em determinado momento mais censurado, em outro momento menos censurado, e em situações específicas, até mesmo a exclusão da tipicidade penal.

Neste sentido também se faz importante o estudo da influência das políticas criminais em determinados casos. A política criminal, conforme se verá adiante, representa, em termos sucintos, a ciência de selecionar os bens jurídicos tutelados penalmente, sendo, portanto, tarefa do Poder Legislativo, pois é através de determinadas opções legislativas que o legislador mensura o grau de censurabilidade que uma conduta, infratora da norma, deve ter ou não. Contudo, há de se considerar, igualmente, que as políticas criminais, no plano fático, são muitas vezes constituídas pelo Poder Executivo e, inclusive, não raro pelo Poder Judiciário.

Também analisa em momento oportuno deste trabalho, as escolas criminológicas, percorrendo toda sua evolução ao longo dos anos, assim como também se estudará a culpabilidade como juízo social, adotando aqui como objeto de estudo, o princípio da co-culpabilidade (que teve como seu defensor originário Eugenio Raúl Zaffaroni).

Pretende-se, por fim, fazer breve levantamento empírico do tema de estudo, ou seja, verificaremos por meio de análises a influência de questões inerentes as políticas criminais na culpabilidade, assim como também a possível aplicação da culpabilidade como juízo social, co-culpabilidade ou, ainda, a culpabilidade do vulnerável em determinados casos concretos. Tal 
pesquisa é um estudo teórico, mas de efeitos práticos, com vista a implementar manobras de segurança pública e de controle social para se chegar a um Direito Penal mais justo.

Uma vez compreendido o significado e a importância da culpabilidade, assim como das denominadas políticas criminais, torna-se necessário evidenciar suas implicações fáticas, demonstrando no presente caso, a problemática que se levanta das influências das políticas criminais no elemento culpabilidade.

Assim, se a culpabilidade, enquanto elemento integrador a estrutura do delito, se resume ao juízo de reprovabilidade pessoal da conduta do sujeito, necessário se faz entender que, para que haja esta desvaloração, deve-se o magistrado se pautar por alguns critérios minimamente fixados. Tais critérios, no mais das vezes, são fixados por questões de políticas criminais, optando o legislador, ora por isentar determinada conduta da pena, ora agravar, majorar e reprovar determinadas condutas.

Neste sentido, a culpabilidade representa um padrão social a ser seguido, isto é, a partir dos ideais socialmente estabelecidos, padronizados e uniformizados por uma determinada sociedade o legislador remete determinadas reprovações do mundo da vida para o mundo da norma.

A questão referente às políticas criminais certamente é tema que merece atenção, estudo e cuidado, pois possui uma margem de subjetividade muito grande, em que cabe ao legislador por questões de relevo social tomar determinada conduta como reprovável ou não. De certo modo às políticas criminais ilustram, grosso modo, a opção legislativa de adequar determinadas condutas aos anseios sociais.

Neste ponto encontramos o sentido de estudar as influências que as políticas criminais exercem sob o elemento culpabilidade, valorando ou desvalorando determinadas condutas frente a situações diversas e diferenciadas. Também neste norte já lecionava o professor Claus Roxin ao apontar que, através das denominadas 'Políticas Criminais', se analisa as questões de conveniência e necessidade da pena.

Portanto, as políticas criminais inserem-se no sistema jurídico penal como resultado intrínseco da relação sociedade-norma, ou seja, através delas pretende-se uma aproximação do Direito Penal à realidade social pelo viés de suas próprias finalidades políticas, superando aqui a problemática da excessiva abstração normativa derivada da dogmática clássica. 


\section{O CONCEITO DE CULPABILIDADE PENAL}

A culpabilidade penal significa, em seu bojo, o grau de reprovabilidade pessoal da conduta de um sujeito, isto é, traduz-se como uma valoração subjetiva, tendente a reprovar ou não, determinada conduta inserida no plano da vida pelo homem.

Neste sentido, é visível compreender que a culpabilidade penal representa toda uma carga axiológica direcionada a um sujeito, com vistas a avaliar sua conduta e as situações que o levaram a se posicionar, deliberadamente, de um determinado modo na circunstância tida como delitiva.

A culpabilidade aflora, assim, como um dos elementos de maior relevância na estrutura do delito, sendo faticamente e inexoravelmente elemento integrante ao conceito analítico de crime, tema este que já foi palco de inúmeros debates levantados ao longo dos anos na seara da Ciência Criminal. Durante grande período de tempo, a culpabilidade penal, ora era vista como elemento da estrutura do delito, ora era tida como mero pressuposto da pena.

Parte da doutrina - dentre eles René Ariel Dotti e principalmente Damásio E. de Jesus, dentre outros - defende (ainda hoje) que a culpabilidade penal é mero pressuposto da pena, pois a partir do finalismo (que deslocou o dolo e a culpa da culpabilidade para a tipicidade) a culpabilidade esvaziouse, sendo ela um requisito para o crime, mas que não se integra ao injusto (não integra a teoria geral do crime). Contudo, parte majoritária da doutrina compreende que a culpabilidade integra o injusto, pois ela possui elementos específicos que condicionam a reprovabilidade.

Nessa linha de raciocínio preleciona Cezar Roberto Bitencourt (2007, p. 329) que os diferentes elementos do crime estão numa relação lógica necessária. "Somente uma ação ou omissão pode ser típica, só uma ação ou omissão típica pode ser antijurídica e só uma ação ou omissão antijurídica pode ser culpável, sendo a culpabilidade elemento do crime".

É de indubitável importância a apreensão deste elemento, pois conforme bem preceitua a doutrina, a culpabilidade representa o juízo de valor sobre a conduta típica e antijurídica, constituindo-se em verdadeiro juízo do grau de reprovabilidade pessoal da conduta (comissiva ou omissiva) de um indivíduo. 
Neste sentido seguimos a orientação de Cezar Roberto Bitencourt (2007, p. 327) ao prescrever que "[...] na culpabilidade concentram-se somente aquelas circunstâncias que condicionam a reprovabilidade da conduta contrária ao Direito, e o objetivo da reprovação repousa no injusto". Welzel afirmava que "[...] a culpabilidade é a reprovabilidade da configuração da vontade." (apud BITENCOURT, 2007, p.328). E, segundo Cezar Roberto Bitencourt (2007, p. 329) "[...] toda culpabilidade é culpabilidade de vontade, ou seja, somente se pode reprovar ao agente, como culpabilidade, aquilo a respeito do qual pode algo voluntariamente".

De acordo com a concepção de Maurach (apud BITENCOURT, 2007, p. 329) “[...] a culpabilidade é a reprovabilidade de um fazer ou omitir juridicamente desaprovado: é uma reprovação dirigida ao autor”. Neste entendimento prescreve Luiz Regis Prado que "a busca da proporcionalidade entre a pena e o delito, no campo penal, e a lógica da compensação entre o dano causado e a reparação, no civil, bem demonstra esse esforço de racionalidade que se funda esse juízo de culpabilidade jurídica" (PRADO, 2005, p. 424).

Neste diapasão, compreendemos que segundo a estrutura do delito somente podemos taxar de crimes aquelas condutas que se enquadram no tipo penal, que estejam prescritas na lei (tipicidade), e também que sejam contrárias ao ordenamento jurídico-penal (antijuridicidade), e que consequentemente possam admitir um grau de reprovabilidade pessoal da conduta do sujeito (culpabilidade).

É segundo este modelo que denominamos de 'sistema tripartido' do crime, pois somente após completo o tipo, a antijuridicidade e a culpabilidade é que podemos obter o crime, propriamente dito.

Deste modo já preceitua Luiz Regis Prado ao afirmar que:

[...] enquanto a ilicitude é um juízo de desvalor sobre um fato típico, a culpabilidade é um juízo de censura ou de reprovação pessoal endereçado ao agente por não ter agido conforme a norma, quando podia fazê-lo (poder do agente/resolução de vontade). O caráter específico de reprovação de culpabilidade reside em não dever ser ilícita por poder ser lícita. A culpabilidade constitui o fundamento e o limite da pena (PRADO, 2005, p. 425, 426).

Ainda nesta temática, já preceituava o mestre Francisco Muñoz Conde (1988, p. 125) que: 
[...] para imposição de uma pena, principal conseqüência jurídico-penal do delito, não é suficiente a prática de um fato típico e antijurídico. Como se deduz de alguns preceitos do Direito Penal vigente em qualquer país civilizado, a prática de um fato delitivo, no sentido de um fato típico e antijurídico, não acarreta automaticamente a imposição de uma pena ao autor desse fato: existem casos em que o autor desse fato típico e antijurídico fica isento de responsabilidade penal. Isso demonstra que, junto à tipicidade e à antijuridicidade, faz-se mister na teoria geral do delito uma terceira categoria, cuja presença é necessária para se impor a pena. Essa categoria é a culpabilidade. Sua função consiste, precisamente, em escolher aqueles elementos, que, sem pertencer ao tipo de injusto, determinam a imposição de uma pena.

É neste entendimento que repousa, entre outros diversos fatores, a grande relevância de se estudar pormenorizadamente e em especial o elemento culpabilidade, apreendendo, por conseguinte seus elementos internos e sua estrutura. Pois conforme bem conotado, o injusto (tipicidade e antijuridicidade) por si só não caracteriza o crime se desprovido de um de seus elementos mais importantes, que é a culpabilidade.

A culpabilidade se entende, assim, como elemento caracterizador do crime, tendo em vista que conduta que não seja culpável se torna notório indiferente penal. Este elemento, portanto, é o que define concretamente a conduta criminosa. Assim, a culpabilidade é considerada verdadeiro elemento integrador da estrutura do delito, o que corresponde afirmar que o crime somente se realiza plenamente com a realização última do juízo de valor (culpabilidade) como elemento fundamentador e limitador da pena.

Nesta ótica assevera Luiz Flávio Gomes (2007, p. 544) em sua ilustre doutrinação que:

É inegável que há muita polêmica sobre se a culpabilidade seria predicado (requisito) do crime ou (só) pressuposto da pena ou constituiria um de seus fundamentos. Discute-se ademais se ela pertence à teoria do crime ou ao mundo da pena. Para nós, a questão deve ser resolvida em favor de uma posição intermediaria: a culpabilidade não faz parte do conceito de crime, ela constitui um dos fundamentos da pena.

Neste posicionamento, entende-se, acertadamente, que a culpabilidade constitui faticamente elemento fundamentador e limitador da pena, integrando 
efetivamente, a estrutura do delito, pois compreendê-la apenas como pressuposto da pena implicaria consequentemente admitir o sistema bifásico, ao qual, seria no mínimo, negar todo o trabalho doutrinário já produzido até então no intuito de garantir, cada vez mais, limitações à força imperiosa do Estado de punir.

Ao analisarmos a estrutura do delito aos olhos do sistema normativo jurídico-penal contemplado pelo nosso Código Penal, mais especificamente o elemento culpabilidade, será perceptível visualizar que o nosso legislador não tratou de definir, exemplificativamente, o conceito de crime, muito menos os elementos integrantes do crime (em especial a culpabilidade). Nosso legislador, apenas se limitou a esboçar de modo muito simplista algumas referências à culpabilidade e suas respectivas excludentes.

Nesta direção, leciona Fernando Antonio N. Galvão da Rocha (1998, p. 390) que:

[...] o primeiro contato com o tema evidencia que o Código Penal Brasileiro não determina um conceito para a culpabilidade, mas indica no artigo 59, que a culpabilidade é um dos critérios orientadores da tarefa de individualização da pena. Consultando-se o art. 29, percebe-se, ainda, que a culpabilidade é um juízo de valor que admite graduação, já que, em havendo concurso de pessoas no fato punível, cada uma destas deve receber uma reprovação distinta, tendo em vista a medida de sua punibilidade.

Neste sentido, muito embora, conforme ilustrado precedentemente, não se possa vislumbrar um conceito efetivo de culpabilidade enumerado taxativamente pelo Código Penal (sendo tarefa, acertadamente, da doutrina), por outra ótica, o legislador deixou resquícios do que seriam excludentes (ou exculpantes) da culpabilidade e também de situações em que a culpabilidade poderia ser diminuída.

Portanto, frente ao todo exposto até então apreende-se que a culpabilidade não é um elemento em que seu conceito se encontra no Código Penal redigido cristalinamente (em que pese pontos singelos relembrados por artigos esparsos e indiretos ao assunto), sendo sua definição de competência doutrinaria, ao qual caberá tarefa de estudo, análise, caracterização de sua estrutura e definição. Assim, cabendo à doutrina o conceito puro de culpabilidade, assevera José Henrique Pierangelli (1987, p. 208)que: 
[...] com um novo avanço da dogmática, a culpabilidade passou a formar conceito complexo. O constante progresso da doutrina permitiu estabelecer a distinção entre a culpabilidade e o injusto, que não se faz fundada tão somente a partir de um critério objetivo-subjetivo, mas sim pelo dever e pelo poder, com isto sendo introduzida na teoria a exigência da reprovabilidade, ou seja, um juízo normativo. Já não bastava para a existência de um delito que o agente tivesse agido, no mínimo com culpa, mas também se reclamava que essa culpa fosse reprovável.

Portanto, é necessário observar que a culpabilidade penal é conceito de custosa construção jurídico-dogmática, sendo que ela deve ser entendida como elemento que integra o injusto e completa o conceito analítico de crime, pois é a partir da reprovabilidade da conduta típica e antijurídica, de um indivíduo que possui imputabilidade, conhecimento da ilicitude e podia se motivar de modo diverso, é que se poderá falar de crime, propriamente dito.

\subsection{A Culpabilidade Penal e sua Evolução Histórica}

Em tempos primórdios, reservados à antiguidade, dos povos bárbaros e germanos, prevalecia a ideia de responsabilização da pessoa com base em uma simples relação causal entre fato e resultado, isto é, o que definia concretamente se uma pessoa seria punida ou não era a simples ideia de um fato lesivo e um resultado danoso, como consequência deste fato, sobrepondo-se, aqui, a chamada responsabilidade objetiva.

Sobre este período da história humana já explicava Anibal Bruno (apud MATTE, 2008, p. 11) ao afirmar que:

[...] as condições da pena sacral e da vingança de sangue satisfaziam-se com o aspecto objetivo do fato punível. Bastava a relação de causalidade física, que prende o fato como efeito ao homem como a sua causa, para determinar a responsabilidade. A pena recaía, então, sobre aquele que praticara o fato, fosse esse voluntário ou não, existissem ou não as condições de imputabilidade, o que juntava na mesma categoria de passíveis de pena os sãos e os insanos ou imaturos penais.

Todavia, conforme prosseguiu a evolução do Direito Penal, percebeuse que somente a mera relação causal entre o fato e o resultado lesivo não 
era suficiente para a responsabilização do sujeito, surgindo assim, em momento posterior, a chamada responsabilização subjetiva, ou seja, só é responsável por um crime aquele que tiver em sua conduta um grau de reprovabilidade.

Neste sentido, a partir dessa significativa evolução nas ciências criminais e, em específico na teoria do crime, verificou-se que para alguém ser punido era necessário uma conduta reprovável, pautada numa ação voluntária e previsível.

Ney Moura Telles em comento ao tema exposto faz notória referência a um trecho do professor Francisco de Assis Toledo (apud TELES, 2006, p. 245), que nos ensina:

[...] não se pode apontar com exatidão, o momento histórico em que tal fenômeno ocorreu, mesmo porque a história do Direito Penal esta marcada de retrocessos. Fora de dúvida, porém, é que, a partir de então, se começa a construir a noção de culpabilidade, com a introdução, na ideia de crime, de alguns elementos psíquicos, ou anímicos - a previsibilidade e a voluntariedade - como condição da aplicação da pena criminal - nullun crimen sine culpa.

Assim, a partir da compreensão pelos homens da denominada responsabilidade subjetiva, pautada na ideia de culpa, surgiu no Século XIX o conceito psicológico de culpabilidade, depois, no Século XX trouxeram o conceito psicológico-normativo e, transformando-se no decorrer do Século XXI, em conceito exclusivamente normativo de culpabilidade.

A teoria psicológica da culpabilidade, segundo leciona Ney Moura Teles (2006, p. 246) é a "[...] ligação entre o agente e o fato, sendo suas espécies o dolo e a culpa, em sentido estrito. Essa teoria constrói a noção de culpabilidade com base nas duas ideias básicas primitivamente construídas: previsibilidade e voluntariedade".

Ney Moura Teles (2006, p. 246) ainda ressalta que:

[...] culpabilidade é, durante anos, dolo ou culpa, em sentido estrito. Como se viu, no estudo da teoria finalista da ação, essa noção já está superada, mas não se deve esquecer que essa ideia representou um grande avanço para o Direito Penal. A estrutura do crime, adotada a teoria psicológica da culpabilidade, mostra a conduta entendida do ponto de vista meramente causal, naturalístico, como simples causa do resultado, 
a ilicitude tal qual se a entende, mas a culpabilidade como o nexo psíquico entre o fato e o agente: dolosa ou culposa.

Entretanto, com a evolução do conceito de culpabilidade na análise da teoria do delito, a teoria psicológica, com o passar do tempo, foi caindo em descrédito. Neste tema pontuava Juarez Cirino dos Santos que os defeitos do conceito psicológico de culpabilidade determinaram seu abandono: “[...] a culpabilidade como relação psíquica entre autor e fato, é incapaz de abranger a imprudência inconsciente, em que não existe qualquer relação psicológica entre autor e resultado" (SANTOS, 2008, p. 284).

Por seu turno, surgiu a teoria psicológico-normativa da culpabilidade, resultado do Século XX, em que segundo tal teoria não bastava o dolo e a culpa serem elementos integrantes da culpabilidade (concepção psicológica), mas era necessário também que a conduta do agente infrator da norma fosse reprovável no sentido de que o sujeito poderia se motivar de modo diverso (concepção normativa da culpabilidade).

Assim, Ney Moura Teles (2006, p. 247) ressalta que:

[...] a teoria recebeu a denominação de psicológico-normativa, uma vez que, mantendo o dolo e a culpa, em sentido estrito, não como espécies, mas como elementos da culpabilidade, acrescentou um novo, de caráter normativo, que é o juízo de valor de reprovação que se faz sobre a conduta do agente, pelo fato praticado, quando presente a exigibilidade de conduta diversa.

Contudo, com o avançar da dogmática jurídico-penal a respeito da teoria do delito, com o surgimento da teoria finalista de crime de Welzel e, com o consequente desprestígio da teoria causalista de crime, o conceito normativo puro de culpabilidade foi o que prevaleceu, deslocando o dolo e a culpa do elemento culpabilidade e passando-lhes ao tipo subjetivo, restando na culpabilidade tão somente o juízo de valor (exigibilidade de conduta diversa), por isto conceito normativo puro da culpabilidade.

Neste sentido elucida novamente Juarez Cirino dos Santos (2008, p. 286) ao prescrever que:

[...] a teoria finalista e o conceito pessoal de injusto de Welzel revolucionaram, simultaneamente, a teoria do tipo e a teoria da culpabilidade, para deslocação do dolo, como consciência e vontade do 
fato, e da culpa, como lesão do cuidado objetivo exigido, da culpabilidade para o tipo subjetivo de injusto, excluindo os componentes psicológicos da culpabilidade, reduzida, enfim, a mero juízo de valor, expresso pelo critério da reprovabilidade que informa a natureza normativa da culpabilidade. Assim, o conceito normativo de culpabilidade inaugurado pela teoria finalista de ação se caracteriza pela seguinte estrutura: a) capacidade de culpabilidade; b) conhecimento real ou possível do injusto; c) exigibilidade de comportamento conforme a norma.

Arrebatando, Damásio E. de Jesus explica que nessa perspectiva "excluem-se do conceito de culpabilidade a maioria dos elementos subjetivos, anímicos ou psicológicos - integrantes do tipo de injusto - conservando-se fundamentalmente o critério da reprovabilidade (elemento valorativo)" (JESUS apud PRADO, 2005, p. 428).

Assim, entende-se que o dolo e a culpa são eliminados do elemento da culpabilidade penal para serem inseridos no tipo subjetivo, restando na culpabilidade tão somente seu juízo de reprovabilidade da conduta do agente infrator.

\section{2 a política criminal e o funcionalismo de claus roxin}

A política criminal representa um dos temas das Ciências Criminais que mais vem ganhando espaço e relevância na contemporaneidade, de tal modo que os discursos que se sucedem na seara do Direito Penal, em suma, se remontam as denominadas políticas criminais.

João Farias Júnior (2004, p. 46) define política criminal como sendo:

O conjunto sistemático de princípios segundo os quais deve o Estado conduzir a luta contra o crime por meio da pena e instituições afins e dos efeitos da pena e de suas medidas afins. A Política Criminal é que deve indicar as mais eficazes estratégias da defesa social. Se a sistemática penal não é idônea para assegurar a proteção social contra a criminalidade, então é preciso mudar a política criminal, operar a reforma, conjurar os males, eliminar os fatores negativos.

Neste sentido, pode-se compreender que as políticas criminais contribuem de forma significativa para a construção de medidas apropriadas 
e eficazes no desempenho de uma proteção social, verificando através da criminalidade os principais meios de controle social do crime.

Conforme este raciocínio aponta Basileu Garcia que:

[...] a política criminal examina o direito em vigor, apreciando a sua idoneidade na proteção social contra os criminosos e em resultado dessa crítica, sugere as reformas necessárias. Verificando se a legislação vigente alcança a sua finalidade, trata de aperfeiçoar a defesa jurídico-penal contra a delinquência (apud FÁRIAS JR, 2004, p. 48).

Assim, torna-se perceptível a apreensão de que as políticas criminais são imprescindíveis para correta mediação de condutas lesivas e não lesivas ao Direito, funcionando como uma balança norteadora de medidas adequadas à função punitiva do Estado e equalizadora ao caso concreto, trazendo consigo valores fundamentais e inerentes a sua sociedade.

Nesta abordagem Fernando Galvão Rocha prescreve que:

A política criminal constitui 'a pedra angular de todo o discurso legalsocial da criminalização-descriminalização'. Vê-se, assim, que os postulados político-criminais devem ser levados em consideração desde o momento anterior à própria existência do Direito Penal (processo legislativo), passando pela fase judicial e executorial, e, mesmo, chegando ao momento posterior, ou seja, quando são recolhidas as conclusões acerca de eventuais efeitos criminógenos de dada tipificação penal, para o fim de propor outros e mais aprimorados encaminhamentos. [...] A política criminal pode ser melhor conceituada como o conjunto de princípios e recomendações que orientam as ações da justiça criminal, seja no momento da elaboração legislativa ou da aplicação e execução da disposição normativa. Coerente com a opção política fundamental do Estado, a política criminal define o que deve ser considerado comportamento delitivo e quais são as estratégias mais adequadas ao combate à delinquência. No que diz respeito às estratégias de atuação prática da Justiça, a política criminal efetivamente influência a escolha e desenvolvimento dos procedimentos necessários à investigação, processo e julgamento dos comportamentos delitivos (ROCHA apud CRUZ, 2009, p. 35).

Deve-se relevar, ainda, que os mais conhecidos movimentos de política criminal são basicamente três: os punitivistas, os abolicionistas e os minimalistas, segundo leciona Luiz Flávio Gomes, que assim expõe: 
O primeiro (punitivistas) acreditam no Direito Penal (a paz social só poderá ser alcançada por meio da intensificação do castigo, da distribuição de penas). Os defensores do segundo não acreditam no Direito Penal (ele seria mais pernicioso do que o próprio crime; 'um mal maior'); os defensores do terceiro desconfiam dele (desconfiam de sua eficácia para resolver os conflitos penais, não admitem que ele possa resolver os problemas cruciais da sociedade, muito menos da sociedade pós-industrial etc.; procuram justificar a existência do Direito penal, mas para ser aplicado como instrumento de ultima ratio, de modo fragmentário e subsidiário e, mesmo assim, respeitando-se todas as garantias penais e processuais estabelecidas pelo Estado constitucional e democrático de Direito (GOMES apud CRUZ, 2009, p. 39).

Assim, pela primeira corrente estavam os autores que defendiam a ideia da pena como retribuição proporcional ao mal cometido, ou seja, o indivíduo deveria ser punido pelos males por ele perpetrados, sendo que a atuação punitiva do Estado deveria se dar de forma plena, possuindo, inclusive, um leque mais ampliado de condutas consideradas criminosas $(\mathrm{O}$ Estado era mais intervencionista).

$\mathrm{Na}$ segunda corrente, por sua vez, se posicionavam os teóricos que lutavam pelo fim da pena e do ordenamento jurídico-penal, pois consideravam a pena meio falho de se corrigir imperfeições, sendo que, do contrário, acreditavam que a pena, apenas, aperfeiçoava as impurezas humanas.

Por fim, segundo o último movimento de política criminal, conhecido genericamente como 'minimalista' se encontram os defensores de um Direito Penal mínimo, pouco intervencionista em causas de irrelevante interesse social. Para tais teóricos o Direito Penal deve ser a ultima rátio e tutelar, tão somente, aquelas condutas que efetivamente são danosas para a sociedade.

O Brasil adotou, assim, dentre os três mencionados movimentos de Políticas Criminais o último (minimalista), pois conforme se verifica da análise legal do nosso ordenamento penal (em que pese alguns retrocessos) sobrepõe-se, indubitavelmente, a teoria do Direito Penal como intervenção mínima, advinda, é claro, da já conhecida construção basilar (por meio de Política Criminal) do princípio da ultima rátio ou da intervenção mínima, princípio este que veio com o fim de limitar o poder punitivo estatal. 
As questões político-criminais adequadamente inseridas no estudo e compreensão do Direito Penal trazem consigo questões das mais relevantes e pertinentes, ao qual, contribuem imensuravelmente às ciências criminais, pois, os fins da pena (por muito tempo já estudado e em muitas vezes entendido como fracassado, se efetivamente analisado o sistema carcerário) deve se orientar por um pressuposto muito básico, o da necessidade.

Isto é, a pena e sua real finalidade deve ser estudada com vistas a sua efetiva necessidade ao caso concreto, de tal modo que a culpabilidade, enquanto elemento que fundamenta e ao mesmo tempo limita a pena, deve ser apreciada levando-se em consideração a ação delituosa, o comportamento do infrator, suas condições de evitá-la ou não (inexigibilidade de conduta diversa) e a real necessidade de aplicação da pena (questões preventivas e de política criminal).

Neste diapasão, questão não menos importante é a de compreender que a culpabilidade penal possui um elo que se liga, fundamentalmente, com as denominadas políticas criminais, principalmente no que tange ao entendimento da teoria funcionalista com suas questões emergenciais contemporâneas de finalidade da pena a luz de razões de política criminal.

No que tange às denominadas políticas criminais, deve-se fazer breve raciocínio no sentido de elucidar que Franz Von Liszt (no final do Século XIX) "afirmou que 'o direito penal é a barreira infranqueável da Política criminal, "” (LISZT apud GOMES, 2007, p. 7), ou seja, as políticas criminais não podem ultrapassar seus limites e entrar no âmbito de atuação do Direito Penal. Entretanto, a partir de 1970 com o magistério aclarador do professor Claus Roxin, apreendeu-se que as questões de políticas criminais são indispensáveis à aplicabilidade e estudo do Direito Penal.

Assim, deve-se salientar com total coerência que tal indissociabilidade das questões político-criminais com o Direito Penal leva a construções de princípios (já bem conhecidos) limitadores do poder punitivo estatal e que são, inegavelmente, produtos das políticas criminais inseridas na esfera do Direito Penal, como é o caso, por exemplo, do princípio da insignificância, princípio da ofensividade, da última rátio, da adequação social, entre outros. Tais princípios trazem em seu bojo toda uma carga valorativa decorrente de questões de políticas criminais que justificam sua inserção no âmbito de atuação do Direito Penal e da Culpabilidade (como grau de reprovabilidade do agente). 
Nos anos 70, surgiu uma corrente na dogmática jurídico-penal denominada como ‘funcionalismo', representada pelo professor Claus Roxin, sendo que tal estudo ficou notoriamente reconhecido como "sistema teleológico-funcional de Roxin" (ROXIN, 2002, p. 82).

O funcionalismo, corrente que, para alguns doutrinadores e estudiosos, veio como superação ao finalismo de Welzel (que superou o causalismo de Liszt) - porque não se esgota no estudo da ação criminosa finalisticamente determinada -, significa que o crime deve ser visto sob um prisma de necessidade da pena, intervenção mínima e eficaz do Estado com vistas à prevenção geral e especial, atendendo sempre a questões de políticas criminais.

Neste sentido, toma nota Andrei Zenkner Schmidt (2007, p. 47) ao apontar que:

Partindo do método funcional dualista, Roxin sustenta a necessidade de os valores tendentes à prevenção geral e especial de delitos influenciarem não só a crítica à legislação penal vigente, senão a própria dogmática penal, ou seja, o modelo roxiano propõe que a Política Criminal oriente a construção do Direito Penal de lege ferenda e de lege lata. Para tanto, sustenta que as concretas categorias do delito - tipicidade, antijuridicidade e culpabilidade -devem sistematizar-se, desenvolver-se e contemplar-se desde um princípio relacionado à sua função políticocriminal. Tal tese, afirma Roxin, não é nova, mas até agora não foram suficientemente postas em evidência as consequências dogmáticas e sistemáticas que devem deduzir-se. Assim, complementa, a unidade sistemática entre política criminal e Direito Penal também deve incluir-se na estrutura do delito e é, portanto, só uma realização da missão que tem firmado hoje nosso ordenamento jurídico em todos os seus setores.

Assim, pode-se verificar que o funcionalismo toma como ponto de partida a ideia de que a pena deve ser orientada teleologicamente, isto é, o crime somente deve ser punido levando-se em consideração seu fim (de prevenção, geral e especial) guiado pela finalidade da política criminal a ele atribuído, conforme o caso concreto.

Neste ponto, Adrei Schmidt (2007, p. 49) expõe que: 
o modelo de Roxin pretende, portanto, uma aproximação do Direito Penal à realidade social pelo viés de suas próprias finalidades políticas, superando-se, assim, os problemas de excessiva abstração normativa decorrentes da dogmática clássica de índole jus positivista. Em termos metodológicos propõe uma síntese entre o pensamento sistemático e o pensamento problemático, pois, afirma Roxin, a vinculação ao Direito e a utilidade político-criminal não podem contradizer-se, mas devem resultar numa síntese, do mesmo modo que o Estado de Direito e o Estado Social não formam, na verdade, contrastes irreconciliáveis, e sim uma unidade dialética.

Outra novidade trazida ao Direito Penal pela ótica do funcionalismo do Professor Claus Roxin é no que se refere à denominada "teoria da imputação objetiva” (ROXIN, 2002, p. 126), na qual, é crime tão somente quando o agente (infrator) realiza um risco não permitido, ou seja, quando o sujeito excede o manifestamente aceito (legalmente) e motivadamente (e quando podia agir-se de modo diverso) realiza o que é proibido (segundo preceito legal).

Deve-se sublinhar quanto a este ponto anterior que a novidade dignamente inserida por Roxin na esfera da culpabilidade diz respeito à culpabilidade ser norteada e orientada por fins de prevenção. E que a aplicabilidade da pena não depende somente da culpabilidade do agente, mas também da necessidade concreta dela (sua real necessidade diante do caso concreto) e seus fins visíveis de prevenção penal.

\section{CONSIDERAÇÕES FINAIS}

A presente pesquisa se esforçou no sentido de apontar que a culpabilidade penal (enquanto elemento que limita e fundamenta a pena) representa um juízo de reprovabilidade dirigida à conduta criminosa e que, ao mesmo tempo, possui um vínculo indissociável com as políticas criminais, pois os valores que norteiam a censurabilidade do agir humano são produtos de anseios sociais expressos pelo poder legiferante.

As questões político-criminais, adequadamente inseridas no estudo do Direito Penal trazem consigo questões das mais relevantes e pertinentes, 
ao qual, contribuem, inegavelmente, as ciências criminais, pois, os fins da pena devem se orientar por um pressuposto muito básico, o da necessidade (conforme prega o funcionalismo).

O funcionalismo, objeto de estudo do presente trabalho, foi a teoria que serviu de trampolim para a difusão da concreta necessidade de estudo e consideração das políticas criminais no Direito Penal, assim como questões de prevenção e necessidade da pena e, também, quanto à teoria da imputação objetiva.

A culpabilidade tem sido, ao longo dos anos, constante objeto de estudo e aprimoramento pelos estudiosos do direito. O injusto culpável corresponde aos elementos mínimos capazes de gerar o poder punitivo do Estado, isto é, através de uma conduta típica, antijurídica e culpável é que se define o crime. Contudo, aspectos de política criminal devem presidir a avaliação da conduta criminosa, ensejando uma reprovabilidade (através do elemento da culpabilidade) baseada em critérios equânimes.

Neste sentido, surgiu na doutrina (por uma questão de política criminal) a teoria da culpabilidade pela vulnerabilidade (co-culpabilidade aprimorada), na qual, defende que o Estado deve ser corresponsabilizado pelas condutas dos indivíduos infratores, pois ele não proporcionou a todos iguais condições de oportunidade. Isto é, o magistrado, no momento de censurar a conduta do indivíduo infrator, deve considerar a culpabilidade pela vulnerabilidade deste sujeito, caso a caso, e quando verificada a culpabilidade do vulnerável deve diminuir a pena deste, de tal modo que a sociedade e o Estado devem arcar com as lesões aos bens jurídicos tutelados se estes não proporcionaram a seus cidadãos iguais condições sociais.

Tal posicionamento ganhou espaço pela vasta doutrina brasileira, encontrando em renomados nomes força para se solidificar. Eugenio Raúl Zafforoni foi seu principal criador, no Brasil encontramos Juarez Cirino dos Santos, Roberto Lyra Filho, Alessandro Baratta, Nilo Batista, Eugênio Pacceli de Oliveira, dentre outros.

Assim, chega-se a ilação de que, de fato, aspectos sociais influenciam na capacidade de autodeterminação das pessoas, devendo a culpabilidade pela vulnerabilidade orientar, conforme a política criminal, a concreta avaliação pelo magistrado da conduta tida como criminosa. Há de se notar, também, que as denominadas políticas criminais participam de forma 
decisiva, sem dúvida, na construção desse exame criminológico feito sobre o indivíduo infrator da norma.

Assim, é cristalino o entendimento de que a culpabilidade é guiada por questões de Política Criminal, pois, certamente, é a partir das políticas criminais que o magistrado, ao apreciar o caso, que lhe é posto, avalia o grau de censurabilidade que determinada conduta criminosa deve sofrer faticamente.

Portanto, tal trabalho chegou à conclusão de que a culpabilidade é conceito complexo e que sua evolução se deu ao longo do tempo como esforço na busca, incessante, de um Direito Penal pautado nos ideais de justiça e igualdade. A co-culpabilidade e a culpabilidade pela vulnerabilidade representam contribuições no intuito de alcançar esses ideais sociais, assim como a política criminal se mostra como principal instrumento de legitimidade do Estado Social e Democrático de Direito previsto na Magna Carta de 1988.

\section{REFERÊNCIAS}

BITENCOURT, Cezar Roberto. Tratado de direito penal: parte geral. 11. ed. São Paulo: Saraiva 2007. v.1

BRASIL. Constituição (1988). Constituição da República Federativa do Brasil de 1988. Diário Oficial [da] União, Brasília, 5 out. 1988. Disponível em:<http://www.planalto.gov.br/ccivil_03/constituicao/ constitui\%C3\%A7ao.htm>. Acesso em: 3 maio 2012.

CONDE, Francisco Muñoz. Teoria geral do delito. Porto Alegre: Fabris, 1988.

CRUZ, Rafael Rocha Paiva. Direito de voto e pessoa condenada criminalmente. 2009. 51f. Monografia (Especialização em Ciências Penais) - Universidade do Sul de Santa Catarina. São Paulo, 2009.

FARIAS JÚNIOR, João. Manual de criminologia. 3. ed. Curitiba: Jaruá, 2004. 
GOMES, Luiz Flávio. Direito penal: parte geral. São Paulo: Revista dos Tribunais, 2007. v.2.

GOMES, Luiz Flávio. O direito penal antes e depois de Roxin. Disponível em: <http://www.defensoria.df.gov.br/sites/300/380/ 00000562.pdf $>$. Acesso em: 12 maio 2012.

MATTE, Natalia Allet. O princípio da co-culpabilidade e sua (in) aplicabilidade no direito penal brasileiro. 2008. Monografia (Bacharel em Direito) - UNIVALI, 2008.

PIERANGELLI, José Henrique. A culpabilidade e o novo sistema penal. Revista dos Tribunais, São Paulo, v.76, n.616, p. 37-51, fev. 1987.

PIERANGELLI, José Henrique. Curso de direito penal brasileiro: parte geral. São Paulo: Revista dos Tribunais, 2007.

PRADO, Luiz Regis. Curso de direito penal brasileiro. 5. ed. São Paulo: Revista dos Tribunais, 2005. v.1.

ROCHA, Fernando Antonio N. Galvão da. A culpabilidade como fundamento da responsabilidade penal. Revista Brasileira de Ciências Criminais, São Paulo, v. 6, n. 24, p. 77-82, out./dez., 1998.

ROXIN, Claus. A culpabilidade e sua exclusão no direito penal. Revista Brasileira de ciências Criminais, São Paulo, n.46, p.46-72, jan./fev. 2004.

ROXIN, Claus. Política criminal e sistema jurídico penal. Rio de Janeiro: Renovar, 2002.

SANTOS, Juarez Cirino dos. Direito penal: parte geral. 3. ed. São Paulo: Lumen Juris, 2008.

SCHMIDT, Andrei Zenkner. A criminologia no Século XXI. Rio de Janeiro: Lumen Juris, 2007, p.47. 
TELES, Ney Moura. Direito penal: parte geral: arts. $1^{\circ}$ ao 120.2 . ed. São Paulo: Atlas, 2006. v.1.

Artigo recebido em: 21/09/2012 Aprovado para a publicação em: 04/12/2013

Como citar: LINO, Allan Vieira. ALMEIDA, Gabriel Bertin. A culpabilidade e a relevância da política criminal. Revista do Direito Público. Londrina, v.8, n.3, p.213-232, set./dez. 2013. DOI: 10.5433/1980$511 X .2013$ v8n3p213. 